\title{
MEASURING PLACE ATTACHMENT, IDENTITY, AND MEMORY IN URBAN SPACES: CASE OF THE WALLED CITY OF LAHORE, PAKISTAN
}

\author{
Armaghan ZAHID (1)*, Damla MISIRLISOY \\ Faculty of Architecture, European University of Lefke, Lefke, 10 Mersin, Turkey
}

Received 02 July 2021; accepted 22 October 2021

\begin{abstract}
Public spaces are essential for any city as they define place character; they are the meeting point for social and cultural actions. Place attachment is moulded by the tie between individuals and places. The research examines the historic streets, which are remainders of their period when the pedestrian flow was predominant and had exceptional qualities that supported social action. The changed settings nowadays might have changed people's views and the investigation was made to question and check individual's common memory and their sensitive ties to the historic streets. The four streets from the Walled City of Lahore were selected upon their significance of history and usage. The questionnaires were prepared and the fieldwork analysis was conducted face to face and selected streets were investigated in the terms of, place attachment, identity, and memory. The outcome proved that there is a promising feeling of attachment towards the selected streets and lacking qualities of a street can be improved if look closely at the worthy streets. The study addressed an important issue of marginalization and the results from the Shah-Almi street shows that their act will create the walled city streets to lose their identity as it is formed by its users.
\end{abstract}

Keywords: urban space, streets, historic cities, place attachment, place identity, place memory.

\section{Introduction}

Space and place are fundamental to our lived world as these two words encounter experience. The place has individual's significance connected to it (Tuan, 1977) and the absence of knowledge of the surrounding settings will lessen the place's character. Where the space is theoretical, it will accept its character from its user, as it comprises the spirit of the individual. Successful cities give a base to the combination of provided meanings; a city that commemorates upgraded human actions stimulates the commitment of memory to turn up (Lynch, 1960). Relph (1976) argued that when an individual could recognize between space and place then that shows they know the concept of a "place" (Jackson, 1995). Sense of place focuses on the importance of the individual's feeling of having a place (Williams \& Stewart, 1998). Spaces ponders essential requirements of a design considering; function; form; location; open and closed spaces; confines; circulation, and private and public parts of the design. Where places should be planned with specific attributes and see the human interaction and they should follow quality, aesthetics, the ways of life, meanings and encounters, character and environments, and a feeling of place (Abusaada \& Elshater, 2021).
Investigators have consistently condemned ideas of place connection, place personality, place reliance, feeling of a place or place a pleasure. They are all known pieces that can be assembled and examined, adding another conclusion is not useful the significant thing that ought to ask now is that how places are essential to individuals as of today. People and places have been changed over time and the study goal was to investigate the noteworthy historic streets of today and to question whether they are still significant to individuals or the community now. In the historic times, the idea of the street was to incorporate both the human and the environment as before everything was easy to contact due to its proximity. Now, people have started to accept modern ideas and planning. These modern settings are different from the historic settings due to their distinguishing change of scale as the new scale allows vehicular flow rather than pedestrian flow. This idea rejects all the qualities, which the street has to offer where its main value was the community-oriented spaces.

The study examines the user feelings and combined meanings so that their contributions can be seen within a space. It sees whether the individuals are committed to their modern settlements and their settings as they have

${ }^{*}$ Corresponding author. E-mail: zahidarmaghan@gmail.com 
been living in this context for a while now. The responsibility of community's symbols might create an attachment to a place as a character gives essence to the public streets, which are being vanished now. There is an end to the meaningful places now. There should be steps taken to preserve and rehabilitate the old settings according to now so that we can live in the modern lifestyle and celebrate the old traditions attachments as well. The knowledge gained from this study can provide a positive impact on its community as it supports community building, which is being diminished nowadays. The changes and improvements can regenerate a place back to life but a first indepth study of the historic settings and the community's needs should to be listened and gathered to provide a meaningful change. The importance and the significance of the historic structures are to be thought about and should blend with the physical perspectives too. Adaptive reuse supports reasonable conditions by utilizing the current structure (Al Braifkani \& Günçe, 2021).

Public connection to a place has always had due to one's fixation and studying in-depth can make us understand its history, features, shared memory, or social life. According to Kyle and Chick (2007), Hidalgo and Hernandez (2001), Hay (1998), Sampson and Goodrich (2009), an individual who is living in a specific setting, their social associations among individuals are a solid marker of public attachment (Raymond et al., 2010). The physical aspect is also important as attachment to a place can be altered in a long-term inhabitation in a specific place or surroundings (Moore \& Graefe, 1994; McAndrew, 1998). Does it mean people can be attached to the new places? It depends on both the physical character and the essence/quality of a place, which shapes a place for its users to get an attachment to. The most important thing for any place attachment is the shared feeling, memory, history, social life, and the built environment. Attachment to place is conceivable if the user intermingles with the people and its immediate context. Human memory is generally from social memories as individuals recall memories from past happenings. Place uniqueness claimed by Proshansky et al. (1983) that considers the feelings identified with actually built environments. So, the study keeps in mind the built fabric as well as it has significance as discussed earlier. Eco-psychology considers the association between the surroundings and the individuals. The connection is centered on the connection set between individuals with their places. The absence of knowledge of the setting reduces the feeling of place and its personality. Scannell and Gifford (2014) planned mental constructs of place in a 3-base, containing process, person, and place and describe who is affixed, what their connection is to, and how psychology assumes its part in setting their connection to places. In the metaphysical term, people are also reliant on their old traditions and memories. Society's memories are connected to the past instances that have happened throughout our life or even before our upbringing this shows that people are reliant upon their old customs (Misztal, 2003). Culture shapes the human mind with memories and suggests the com- munity to build its physical fabric which supports their customs and traditions. Cultural linkages to the past are the key to the making of grounded associations to places. These old traditions or settings make them feel "related" to an environment (Hay, 1998). If customary practices are thought to be spaces then a solid connection will be packed with recollections, which will straight forwardly relate itself from its old images and experiences related to historic spaces, thus creating a sensitive tie for its users (Scannel \& Gifford, 2014).

The study sees if the user chooses modern over traditional, only then we can perceive if historic meanings are worth improving and rehabilitating. The notion of the study was to find out the street features/components, which give the street its attachment to which the individuals are concerned with. Seeing their personalized spaces and see the role of meanings and symbols that personify their affiliation to the city streets. The learning recommends a potential proposal that can help historic streets that has a worth of relics without transforming them into products for example gallery/exhibition spaces or a business center. As per the exploration of (Kølvraa \& Knudsen, 2020) says that the historical centers will transform, establish new associations, and push disagreeable plans, and innovatively re-evaluate crowd commitment and inclusion. Memory activism is a vital arising idea; it is presently applied to activist gatherings that tackle the history to make right and supporting cases about the requirement for a social change. It offers verifiable equity, common freedoms, compromise, and peace building (Bukowiecki et al., 2020; Kølvraa \& Knudsen, 2020).

To conclude up the idea of the streets have changed into more isolated spaces and it's have lost its worth as all inclusive spaces and lost its implication as "gathering places". The study aimed to find out street components that give the street its attachment, because of which individuals feel responsible for as a customized space and see the job of symbols and implications in further building up that customized relationship. The study was confined to the symbols or qualities of its fabricated environment of the Walled City of Lahore by its present local but this thought was simply considered as a general. As the study was only centred on to address the case that they are still connected to the walled city? When results same it showed that few sections don't have connection or hold importance for their local as displayed by the scientific information. The review can be utilized as a base for additional exploration in this field. The study can be reached out as such that the street components are asked by its community of the Shah-Almi road and that will help create a new identity/the lost identity. Further examination needs its user input for better working.

\section{Theoretical framework}

\subsection{Concepts of place attachment, place identity, and place memory}

Human societies have changed over time from living in small groups to present-day modern living. Lynch argues 
that the occupants have elongated connections with their old roots as they can envision it as loaded with recollections and connotations (Abusaada \& Elshater, 2020). Culture does not embody few components, which can be dismantled and put together: culture has to be lived (Canizaro, 2007). Taha and Gami (2010) argues that the country's faiths are known from the combined understandings of its individuals. Their faiths can be made with connections to their built environment, occupation, period, and practices. Hence, it must be inspected in detail both physical and non-physical perspectives as the two-state beliefs and individuality. Social qualities could be perceived top to bottom to see its noteworthy cycle with its fabricated climate. Ethnic morals could be appreciated in detail to check its historic development with its made settings (Taha \& Gami, 2010). The development of the community is from the acknowledgment of their shared morals and individuality which is linked with their cultural performs and objects Associations that tie individuals to regular commitments and duties are vital for human growth. Nowadays, there is traditional disregard because of the expansion in present-day modern trends and individuals disregard the cultural intake, which contributes to the character of the place. The modernity didn't stand firm on any footing of the traditional design and thoughts however some groups worldwide declined this thought and said to focus on both practices together giving significance and extension to the memorable time (Un-Habitat, 2011). Additionally, the anthropologist must research the outcomes of metropolitan advancement, for instance, the presence of tall structures close by neighbourhood, which will cause brutality (Haughton \& Khandker, 2009). Any society in the metropolitan sites stretches the get-together of individuals, constructs passionate ties, and outlines objectives for a person. These gatherings can support and give a quality of living. These groups incorporate a variety of exercises that offers numerous alternatives for their individuals (Elshater, 2012).To accomplish this excellence of living one must learn the nearby built-environment inside and out and perceive how it can been handed. As Jacobs proposed when the improvement cannot be given, it should be done thoroughly. It is a progression and not an assembly of principal products. Eliot (1949) mentions that for culture to proceed there should exist dependence on previous traditions and customs. Looking at the past can be utilized to know the general public's way of life in a specific setting. Eliot expressed that every area has its way of life, which can blend and enhance, the way of life of the attacked settlements. Eliot suggested that there should be an equilibrium of harmony and variety and said if variety matched one another then the general public would turn out to be excessively one-dimensional and grey (Eliot, 1949). The cultural tactic for architecture is significant as it reflects place culture. Geroter (2007) talks about Hans Hollein idea that culture will influence the development of space for instance space formation and space order. He stated that these customs, symbols, or representations make rationale in the architecture field. Every human settlement had its points of faith, and architecture was utilized to imply their customs or morals. The field of architecture is the mirror of people's actual culture and so the general public is liable for making such (Ettehad et al., 2014).

\subsection{The importance of place determinants/values}

Once space forms significance or it gets some kind of definition or meaning appended to it, it turns into a place. Space doesn't have personality until it is established in occasions or fiction. Simply, significant spaces make a "place" (Tuan, 1977). Attachment is referenced as a connotation, which is set up inside an individual from its close setting. A place can be referenced as an area that grips significance for an individual or a group of people (Low, 1992). A place at all times incorporates an actual site that shows a place with its important history (Low, 1992). The connection happens because of the solid natures towards the images of a place. When investigated to place character, it's about a person's nature, which met up through the people's affiliations and connections with their general surroundings. To acquire an individual's identity theory, an individual should differentiate themselves and their built environment (Lalli, 1992). The most extreme predominant recollections come from lived encounters that originate from places when lived in a stretch in a particular location (Marcus, 1992). Some intricate components provide this communication to occur, this may incorporate experience, purpose, program, or authentic features. Different components that are fundamental for the people in forming identity are symbols. These may hold significance for a bigger society or might be interesting to individuals of that particular local community these extra components of fluency help individuals to situate themselves in their specific built environment. Finally closing to the place memory, there is a relative term called "shared memory", or "social memory" which is widely utilized by sociologists and analysts (Halbwachs, 1925). Social recollections might be associated with occasions that happened throughout our lifespan, or even before being conceived.

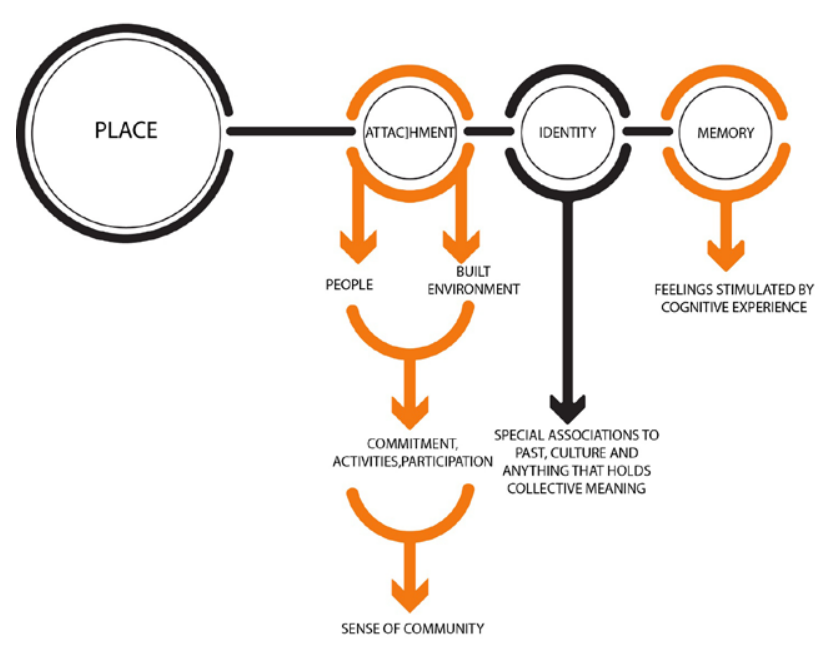

Figure 1. Place determinants/values (developed by Zahid, 2021) 
What is recollection did not depend on one's experience, however on past experiences; it depends on social behaviours of the past. Robust responses happen during identity development (Bellelli et al., 2010). Figure 1 shows the 3 determinants being divided and see how they play out for the place itself.

\section{Methodology}

\subsection{Data collection}

The study incorporates the assessment between various public streets of the Walled City of Lahore and sets forward their uniqueness regarding place attachment, memory, and identity through their users' chance encounters. Concerning the methods of this study, first, literature survey was conducted which relates to the place attachment, identity, and memory. The second step was intricate with the making of the survey-based questionnaire, which came about after the analysis of the fieldwork supporters. The questions were made specifically on the 3 values, which were place attachment, identity, and memory concept and the questionnaire was adapted from the following researches (Raymond, 2010; Williams, et al., 1992; Williams \& Vaske, 2003; Kals et al., 1999; Hidalgo \& Hernandez, 2001; Lewicka, 2011).

Questionnaire:

- Which street is special to you?

- Does this street mean anything to you?

- Do you feel connected with this street?

- Do you like living in this street?

- Do you like spending your time here?

- Are the people still dependent on these monuments?

- Is this street better than the other streets here?

- Doing such activities here is important to you?

- Is this space special to you and your family?

- Do you like living here with your family?

- If your family moves out of the city, will you move out too?

- Do you feel any bond with the people here?

- Do you feel connected to the culture of this building?

- Do you feel at peace when you live here?

\subsection{Case study evaluation}

The next step was to conducting the questionnaire in the selected streets, which was done face to face. A sum of 220 surveys was conducted in the five variant streets of the historic walled city and they were examined in terms of the place attachment, identity, and memory concept. The number of the survey is decided according to the number of users on the streets per day. The survey was conducted with the $10 \%$ of the users of each day. The 5 measures used in the survey can be seen from the Table 1.

The user in the survey answers who answered from 1 to 3 shows a positive yes, where the user who answered above 3 is considered as a negative. The Table 2 shows the Likert scale.
Table 1. The five scales of the questionnaire (Zahid, 2021)

\begin{tabular}{|c|c|}
\hline 5 scale & Answer \\
\hline 1 & Definitely Yes \\
\hline 2 & Yes \\
\hline 3 & Neutral \\
\hline 4 & No \\
\hline 5 & Definitely No \\
\hline
\end{tabular}

Table 2. Understanding the Likert scale (Zahid, 2021)

\begin{tabular}{|c|c|c|c|}
\hline 5 scale & \multicolumn{3}{|c|}{ Answer } \\
\hline 1 & Definitely Yes & $39 \%$ & \\
\hline 2 & Yes & $44 \%$ & \\
\hline 3 & Neutral & $11 \%$ & 4.14 \\
\hline 4 & No & $4 \%$ & \\
\hline 5 & Definitely No & $2 \%$ & \\
\hline
\end{tabular}

\section{Case study: The Walled City of Lahore}

\subsection{Historical background}

There are four states of Pakistan, having separate natural features, customs, and linguistics, each state continually intermingles with one another, which permits them to gain knowledge with one another's set of experiences and customs (Mumtaz, 1985). The start of Lahore according to Hindu classic, Lord Vishnu's embodiment is Ramayana who had two children, Lava (Luv) and Kush people accept that these two children founded the city of Lahore. The city was established around $1000 \mathrm{CE}$ and was bordered by mud-brick for safety reasons. The old city was developed naturally and covers an area of 461 acres. The city contains a blended-use typology of private, commercial, religious, and surprisingly manufacturing sectors. These areas blend private and public spaces very well providing opportunities for relaxation along with work (Ezdi, 2009) the period that thrived was the Mughal period (1525-1759). They provided Lahore with unique landmarks. During the rule of Akbar and Shah Jahan, the city was full of the populace there were no assaults from the outside and the city became more populated (Fazl, 1978). During the British period (1846-1947) there was a development of new weapons for war which prompted a period where the old of walls did not provide security and it lost its significance and got removed. The bricks were then utilized for the new developments for a strategic purpose. British introduced Railway Station and this opened doors for new business and the city started to expand towards the outside (Merchant, 2017). In the 1970s, individuals who could manage the cost of better modern life, moved to the new parts of Lahore (Pakistan Environmental Planning and Architectural Consultants Limited, 1993) This created issue of attachment among the evacuated peoples as it affected the worth of the historic city Abusaada and Elshater (2021). Unexpected changes during the 20th cen- 
tury made the city develop outside. This new changed the concept of the street. The viability of the roads that were for the vehicle traded the streets, which were sensitive and rich in culture. These roads lost the job of passer by and street quality and as a result created a social decline (Yasin, 2012). The old city followed some special attributes from the upgraded one, where the city was created to feel secure and yet provide solid social collaboration. This memorable street follows a complex organization of cultural and social activities and encourages the user to walk. This new expansion outside the walled city failed the neighbourhood planning, the streets whose goal was to join the spaces and empower individuals to connect. It created a community-oriented place where one's culture was celebrated. These historic streets still work and have their glamour and intangibly. The study was done to check the place attachment scopes and see its workability of the historic streets and see what lacks now.
The historic city has thirteen entryways to the city to which at present there are just 6 entrance doors that still exist, although these gates got dismantled during the British period but still give entry towards the inside. See Figure 2 for access to the city.

The streets, which were picked for the review, were made dependent on the most. Streets with were mixed-use and had the historic structures were chosen as they create place identity. The guide given by The Walled City of Lahore Authority (Figure 3) shows that the significant spaces which are in the walled city. The fundamental marketplaces are the Dehli, Shah-Almi, Mochi, and the Masti bazaar street. They have customary to standard everyday items, which are needed. The Mochi, Masti, and Dehli street are the oldest and the most customary ones. Shah-Almi Bazaar is modern and has not many traditional structures. Shah Almi Bazaar could be furthered explored where the diverse working squares could be investigated and contrasted with each other in terms of place attachment.

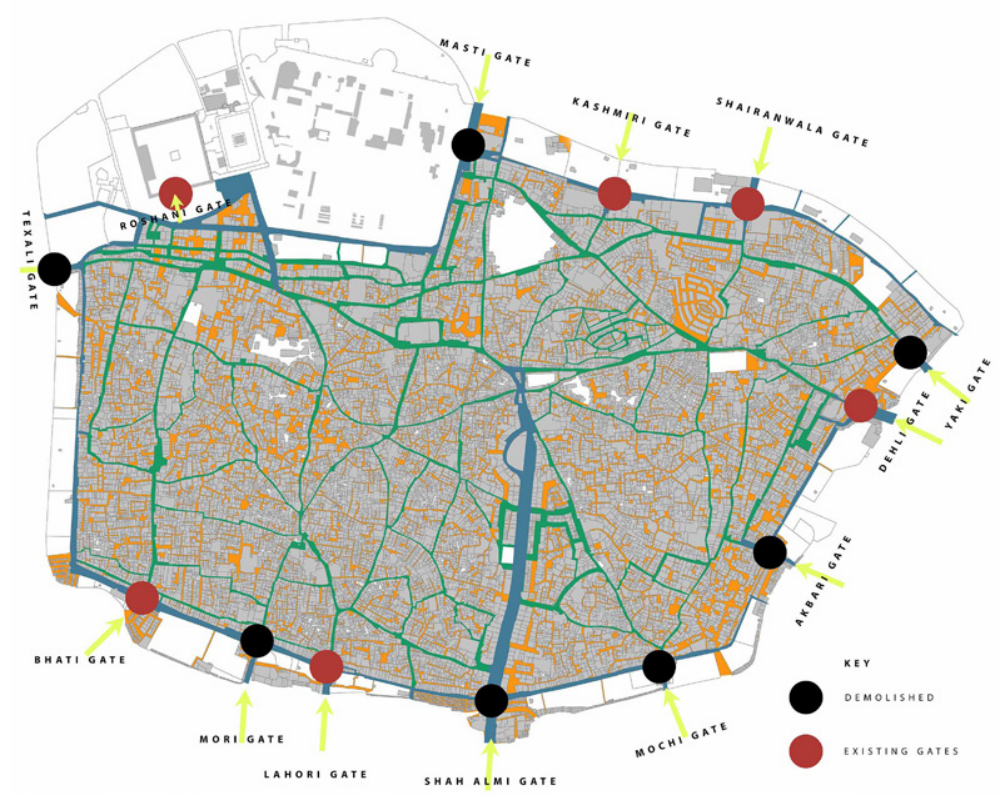

Figure 2. Walled City of Lahore (source: Zahid, 2021)

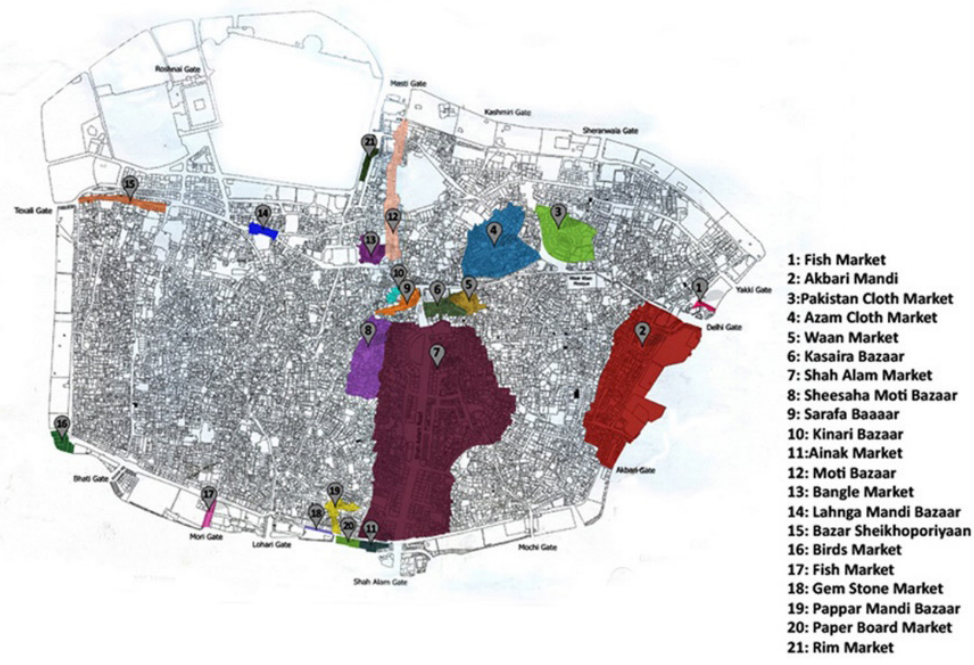

Figure 3. Main Bazaar streets of the Walled City of Lahore (source: Walled City of Lahore Authorities, 2021) 


\subsection{Introduction to the selected streets}

This study was essentially centred around these four bazaar streets, as they are significant bazaars of the Walled City of Lahore the Figure 4 shows their locations. Delhi Street is the single significant walk-ins of the historic city; it is most celebrated and broadly utilized. This street was expanded during Shah Jahan's reign when be built the hammam and the different traditional landmarks, for example, when they built the Wazir Khan mosque and the golden mosque the whole street and the surrounding area were changed into a blended-use street. On the ground floor, there are shops and the upper floor has livable spaces. The square of the Wazir Khan was the focal point in the past where all sorts of gatherings, political or social exercises were held and it has done its use for more than 350 years. This square brought together all the poets, artists, writers, and academics to meet up and talk about their ideas. In this street, one can purchase conventional garments, backpacks, shoes, or can even consume traditional Pakistani food. Mochi street; Mochi in Urdu, is known as a shoemaker, in legends, it is assumed that the name was derived from Moti which was a guard of this gate in the Mughal period. The watchman cared for this entryway throughout his entire life. Mochi Street is renowned for kites, toys, dried fruits, and shops of firecrackers, and it's famous for gathering in Maharam. Significant gathering points incorporate the Mochi bagh where numerous legislative pioneers meet the community. Masti street; its name Masti was gotten transformed from Masjid known by the famous Mariam Zamani Mosque. The imperial ladies of the fort utilized that way to go to the mosque. Over time, the British made this way, and after that Rim Market violated this cleared territory. This bazaar has Hindu temples and mosques close by and this shows that individuals can blend and live respectively, concerning their differentiation of religions. This bazaar street is known fundamentally for its greatest shoe shops. This old bazaar street is honoured with remarkably skilled workers for Hand created instruments decorations and even gives skills of hand-bind books. Shah-Almi Bazaar; This entryway took its name from Shah Alam who is the son of Aurangzeb. This bazaar is well known for its electrical products, toys, cooking wares, cooking pots, and home décor items. During the division of Pakistan and India in 1947, the whole territory was destroyed in the fire and after that, it was reconstructed but was modernized this new presence has forgotten the overall imagery of the traditional practices and the urban environment of the Walled City of Lahore.

\subsection{Assessment of the survey}

From the survey, it is well seen (Table 3 ) that most of the user is male as the inner city is a male dominant you do see females as well using the street as they come to watch their youngsters' playing or spend time with their loved ones and friends. Females help their guys with their business by helping them in making customary garments or other traditional stuff. Continuing to the age, the age seen proper for this examination was between the age of 18 $45+$ as 18 is a grown-up age. The fundamental of the study was to pick individuals, which had a superior comprehension of things as they have mature sentiments. Most of the questions were asked to the age of 25 as they are a mature age group and can provide more fruitful feedback. The significant thing considered for this study was the length

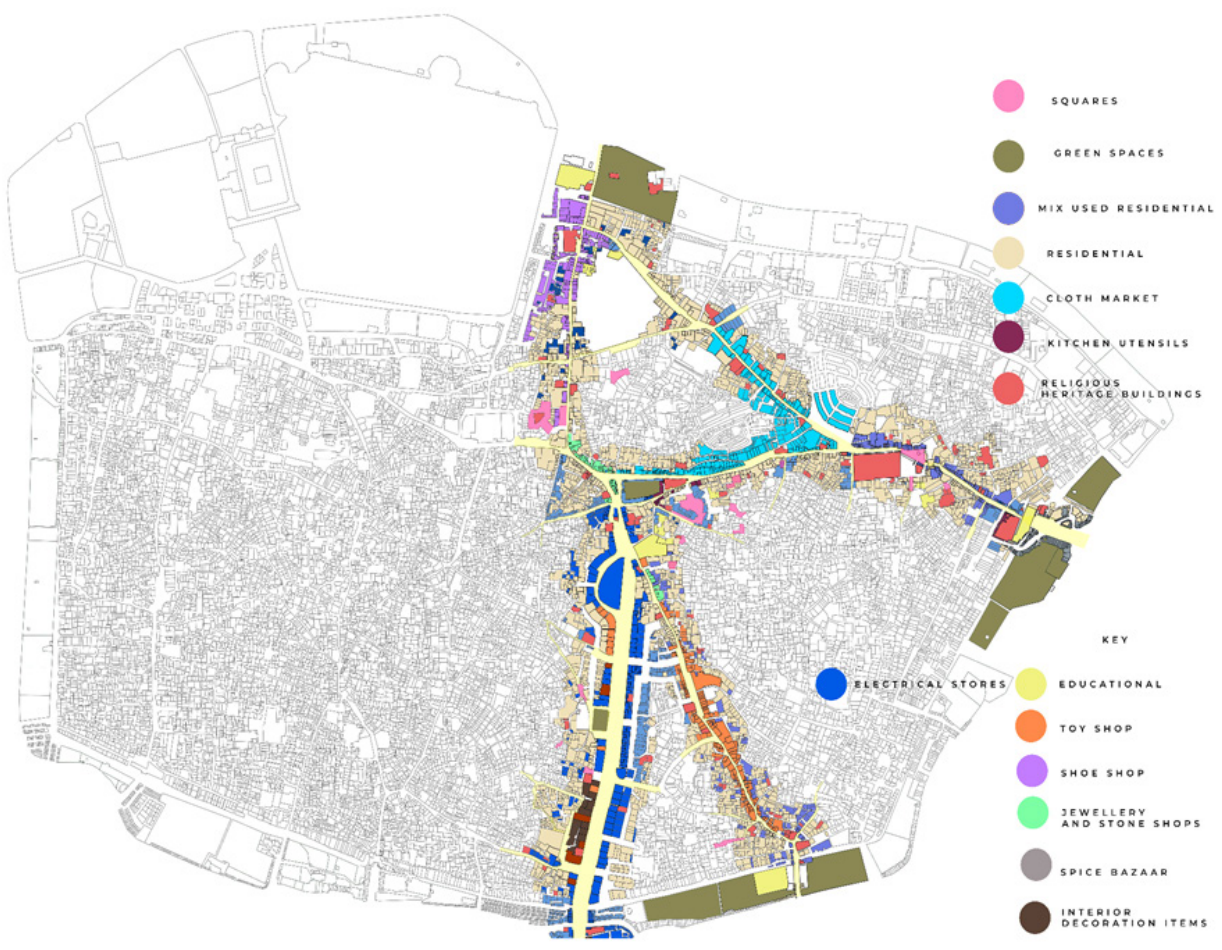

Figure 4. Selected streets in Walled City of Lahore (developed by Zahid, 2021) 
Table 3. The user analysis

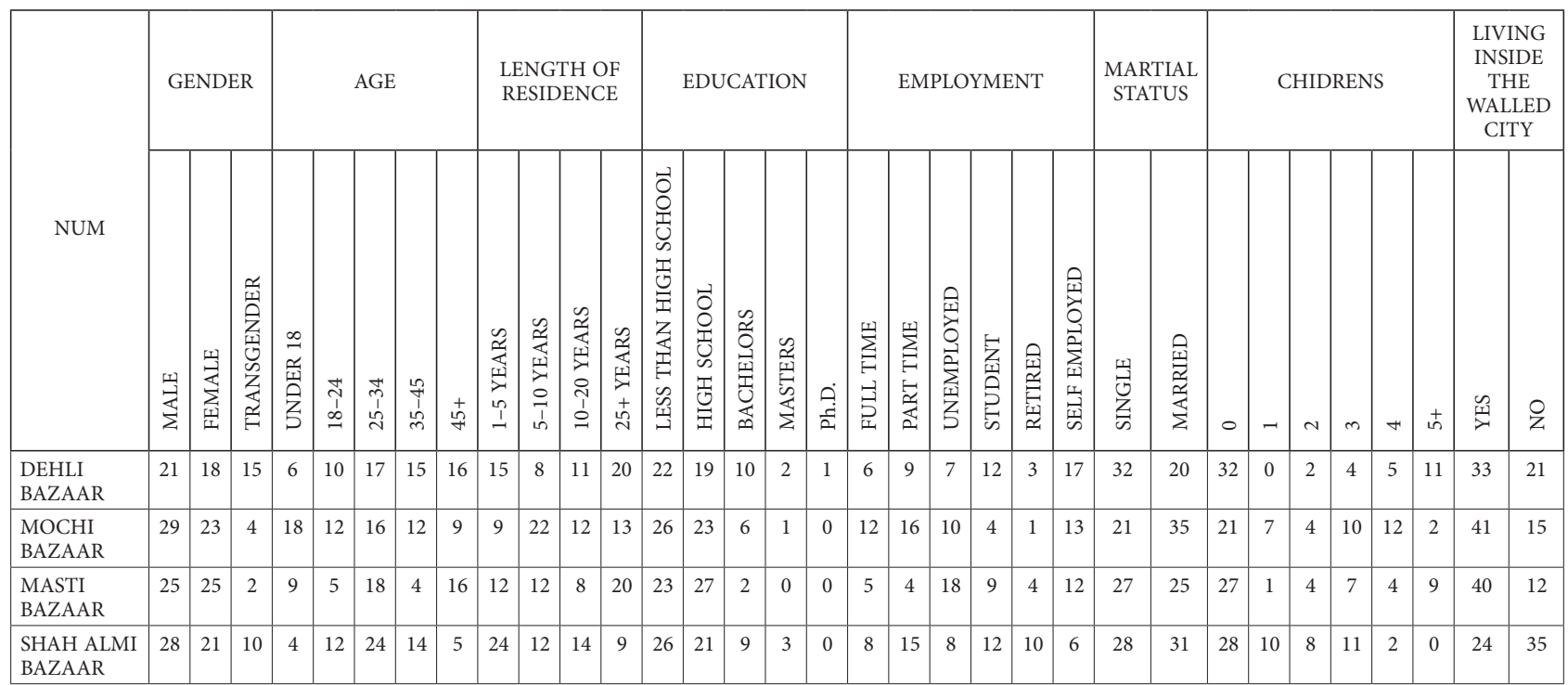

of the stay as the primary focus, as a longer stay makes a solid place connection. The lowest length of stay considered for the study was from 5 to 25 years. The remaining investigation of the education, work, and married status was seen as less significant for the place connection but it was done to get an overall foundation of the respondent.

The limitation of the study was only restricted to the 4 streets of the walled city and its finding will support future considerations for the rehabilitation of the sites. The study does define which elements are important that could be used for the upgrading of the street but further study should be conducted to check whether the current user wants it on the street or not. The street, which lacks from the other three, is the Shah-Almi street and a separate study should be made for its better place attachment. The survey was partitioned into three sections place attachment, identity, and memory. These inquiries were then isolated by their claims like for instance place attachment shows connections among individuals and location, as the local is appended and formed by its assembled environments. The attachment can be formed by the history of the place or by its set of experiences. The inquiries that reflected meanings to the spaces were isolated into the Place identity part and the last part was divided into the reflected contemplations and sentiments about the place as memory is experienced by a subject through individual sensations of a place from lived encounters. A sum of 220 surveys was made in the five different bazaar streets of the historic Walled City of Lahore. For the analysis part, some predictions were thought about as it would help to judge the street and these statements could be tested to whether they are true or not.

- Hypothesis 1: Is there some normal connection between the distinctive streets connections? The prediction is thought to be towards traditional than modern.

- Hypothesis 2: The old reminder/structures will change the place connection of its users.
- Hypothesis 3: Longer stay inside the city will show a positive result.

- Hypothesis 4: Nationalized streets that have meaning and are more customary will prove that there is a more grounded place connection due to its character.

According to the first part of the place attachment, the question asked people to tell which street is more meaningful to them and Figure 5 shows its results.

From the Table 4 and the Figure 5, it is seen that the Delhi street attachment is $34.4 \%$ which shows that the connection is fundamentally towards the traditional neighbourhood over the advanced as Shah Almi door has only $16.7 \%$ attachment overall. Shah Almi road is a street used mostly for business purposes. This road got so uninhabited during the partition when the entire region was torched down and the individuals moved to the other parts of the city Shah-Almi was rebuilt but was modernized and lacks the conventional qualities of the walled city. Mochi and Masti Street resulted in a similar attachment, which proves that the connection is towards the traditional as perceived by hypothesis 1 .

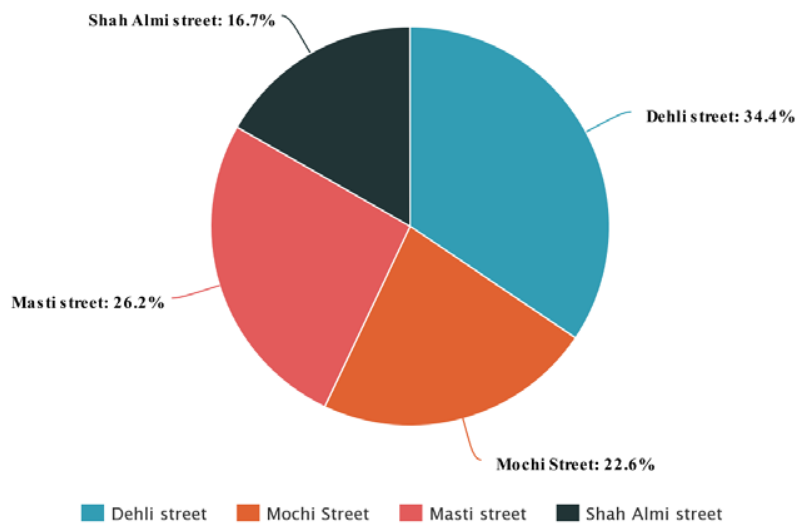

Figure 5. Place attachment from the selected four streets 


\begin{tabular}{|c|c|c|c|c|c|c|c|c|c|c|c|c|c|c|c|c|c|c|c|}
\hline & 己 包筂 & ì & & 号 & 空 & ふें & 商 & ذें & 家 & वें & ذిे & ㅇํํ & \begin{tabular}{|c|}
$\stackrel{0}{\circ}$ \\
ลे
\end{tabular} & ஸें & $\stackrel{\circ}{\circ}$ & ঐे & $\stackrel{2}{2}$ & 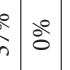 & लें \\
\hline & 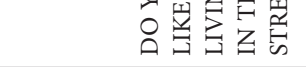 & & & $\underset{+}{F}$ & & 禹 & & & $\stackrel{\vec{m}}{m}$ & & 留 & & & & 出 & & $\begin{array}{l}\infty \\
\substack{\infty \\
i}\end{array}$ & $\begin{array}{l}8 \\
i \\
i\end{array}$ & $\stackrel{\circ}{\gtrless}$ \\
\hline & & î & $\stackrel{\circ}{12}$ & $\stackrel{\circ}{\rightrightarrows}$ & 今े & $\stackrel{\circ}{\circ}$ & 离 & 离 & 品 & ळें & ओं & 品 & $\stackrel{\circ}{2}$ & ڤे & $\stackrel{\circ}{1}$ & ปั̀ & ڤ̊ำ & | & $\stackrel{\circ}{m}$ \\
\hline & 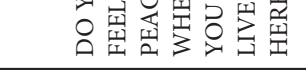 & & & $\stackrel{\vartheta}{\vec{F}}$ & & & & & $\stackrel{+}{\circ}$ & & 禹 & & & & 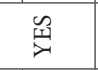 & & $\stackrel{\infty}{i}$ & Si & \& \\
\hline 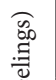 & ○ & 总 & $\stackrel{\circ}{\circ}^{\circ}$ & 总 & ֻें & i̊ & 官 & $\stackrel{\circ}{\infty}$ & 宓 & ڤें & $\stackrel{\circ}{\circledR}$ & 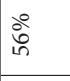 & 亏ें & ذें & $\therefore$ & 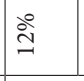 & 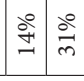 & : & पें \\
\hline 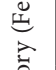 & 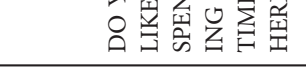 & & & ֶָ. & & 留 & & & $\stackrel{n}{m}$ & & 垚 & & & $\stackrel{\sim}{\stackrel{\sim}{+}}$ & 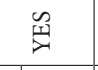 & & 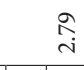 & $\hat{i}_{i}$ & $\stackrel{8}{z}$ \\
\hline 苛 & & ले & 今े & ڤ̊ & $\stackrel{\circ}{\circ}$ & 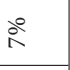 & 今̀ & 寅 & $\stackrel{2}{3}$ & ఫें & & مें & 容 & $\stackrel{8}{\circ}$ & 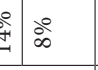 & ڤ̊ & î̀ & \begin{tabular}{l|l|} 
\\
\multirow{2}{*}{}
\end{tabular} & 今ें \\
\hline 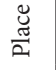 & 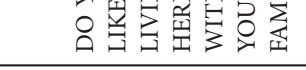 & & & $\stackrel{\infty}{\infty}$ & & 留 & & & ?ִ & & 玨 & & & $\vec{\infty}$ & 䍒 & & $\underset{\substack{+ \\
\text { i } \\
i}}{ }$ & $\begin{array}{l}\text { ì } \\
\text { i }\end{array}$ & $\stackrel{8}{z}$ \\
\hline & & ळ̊ & 㝕 & $\stackrel{\circ}{\circ}$ & $\stackrel{\circ}{\stackrel{े}{~}}$ & $\stackrel{\circ}{\leftrightarrow}$ & $\stackrel{े}{\vec{े}}$ & 总 & ذे & ปें & $\stackrel{\circ}{\circ}$ & 高 & 品 & i⿱⺈ & 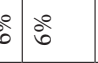 & $\stackrel{\circ}{\circ}$ & ओे̀ & 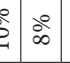 & $\therefore$ \\
\hline & 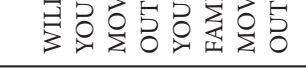 & & & 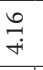 & & 留 & & & ర్ల & & & & & 命 & 这 & & 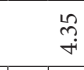 & 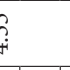 & 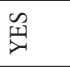 \\
\hline & 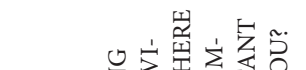 & ฏें & ळे & $\stackrel{\text { ڤे }}{\mathrm{m}}$ & $\stackrel{2}{\circ}$ & ลे & ڤેे & 离 & - & ఫे & ఏ్ & in & 离 & 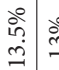 & 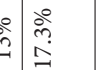 & $\stackrel{\circ}{\stackrel{\circ}{~}}$ & 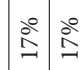 & $\therefore$ & 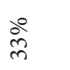 \\
\hline & 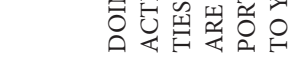 & & & 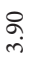 & & & & & $\stackrel{\infty}{m}$ & & & & & 落 & & & $\stackrel{\infty}{i}$ & $\begin{array}{l}8 \\
i \\
i\end{array}$ & $\stackrel{\circ}{z}$ \\
\hline & & 宮 & : & | & 竞 & ふָे & 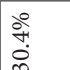 & $\mid$ & | & 方 & $\stackrel{0}{\infty}$ & \&े & ลें & ळे ذे & : & ذิ่ & 亏ें & 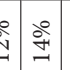 & ڤें \\
\hline & 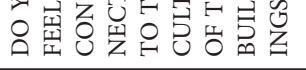 & & & $\stackrel{m}{\longrightarrow}$ & & 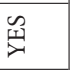 & & & fi & & & & & $\stackrel{n}{\stackrel{n}{+}}$ & & & ๙ู & $\hat{\mathrm{j}}$ & $\stackrel{\circ}{\mathrm{z}}$ \\
\hline & & 总 & $\stackrel{7}{7}$ & ळें & $\stackrel{\circ}{\leftrightarrow}$ & ふे & बें & ฌें & 产 & ఫे ఫे & $\stackrel{\infty}{-}$ & 商 & $\frac{\stackrel{\rho}{m}}{m}$ & : & $\stackrel{\infty}{\infty}$ & $\stackrel{\circ}{\circ}$ & 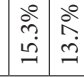 & : & ì \\
\hline 言 & ó & & & 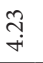 & & 㝝 & & & $\stackrel{\text { fq }}{m}$ & & 出 & & & 㐫 & 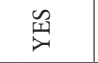 & & 年 & fi & そ \\
\hline $\begin{array}{l}\overline{\tilde{U}} \\
\frac{\tilde{U}}{\alpha}\end{array}$ & $\tilde{\ddot{\tilde{x}}}$ & भे & สิ & $\stackrel{\circ}{\infty}$ & $\therefore$ & $\stackrel{\circ}{\circ}$ & مे & $\mid \begin{array}{l}0 \\
\stackrel{\circ}{+} \\
\stackrel{i}{+}\end{array}$ & 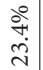 & 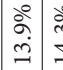 & 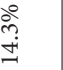 & §ै & aें & $\stackrel{8}{\circledR}$ & $: 3$ & ঐें & $\stackrel{े}{\triangleq}$ & : & ळें \\
\hline & 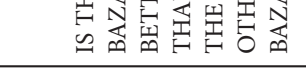 & & & $\stackrel{\infty}{\not \rightarrow}$ & & 留 & & & $\underset{\infty}{\infty}$ & & 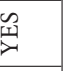 & & & 命 & 乐 & & $\stackrel{2}{8}$ & Si & そ \\
\hline & 品 & 㠃 & 今े & $\stackrel{े}{~}$ & i⿱宀 & i⿱ & 2 & サे & in & 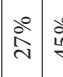 & ஓे & ळे & 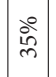 & $\stackrel{\circ}{\circ}$ & $\stackrel{\leftrightarrow}{\circ}$ & 总 & $\grave{2}^{\circ}$ & 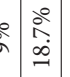 & $\stackrel{\circ}{i n}$ \\
\hline & 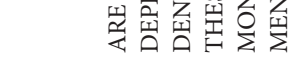 & & & बे & & 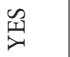 & & & הิ & & 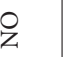 & & & $\stackrel{\infty}{\stackrel{\leftrightarrow}{+}}$ & ભ્ર & & ત્̀ & y & 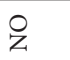 \\
\hline & & مे & $\frac{8}{7}$ & فㅇ. & $\stackrel{\circ}{\circ}$ & ì & à & 突 & | & ล̊ำ & ले & 总 & $\frac{\circ}{m}$ & ఏे & : & 今ें & $\stackrel{2}{2}$ & 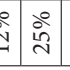 & अें \\
\hline & 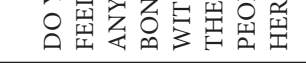 & & & 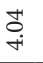 & & 迸 & & & $\overrightarrow{\sigma_{j}}$ & & 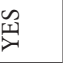 & & & 市 & 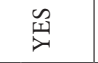 & & ๙ู & Sis & 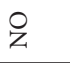 \\
\hline & ڤํㅓㅇ & के & ฌे & i̊ & $\therefore$ & $\stackrel{\circ}{\curvearrowright}$ & के & 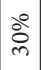 & 定 & ลำ & $\stackrel{\circ}{~}$ & 今े & ڤें & $\stackrel{2}{\triangleq}$ & 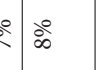 & 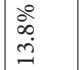 & 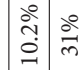 & :ُ & ओें \\
\hline 5 & 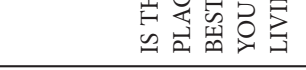 & & & 菅 & & 留 & & & 6 & & 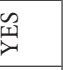 & & & ळे & ભ્ર & & $\stackrel{\infty}{i}$ & i & 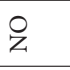 \\
\hline 䔍 & 番。字究焉。 & مें & $\stackrel{\circ}{\circ}$ & ळें & $\frac{\circ}{\dot{m}}$ & 今̊ & 票 & 産 & iे & 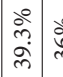 & @i & ঐ̊ & $\stackrel{\circ}{\circ}$ & ఏे & 吾 & ڤે̀ & 辛 & 年 & in \\
\hline$\underset{\mathscr{y}}{\tilde{g}}$ & 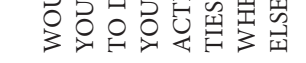 & & & 2 & & $\stackrel{8}{z}$ & & & 8 & & そ & & & ले & z & & $\stackrel{+}{+}$ & 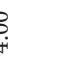 & 出 \\
\hline & 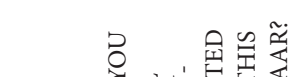 & ì & 今े & ஓें & 帝 & 今 & iे & ڤें & 品 & $\stackrel{\circ}{\circ} \stackrel{\circ}{\circ}$ & ओे & $\begin{array}{l}\text { in } \\
i \\
\infty \\
\infty \\
\infty\end{array}$ & $\stackrel{\circ}{\circ}$ & 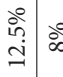 & 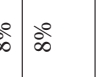 & i̊ & $\stackrel{亏}{\beth}$ & 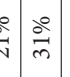 & $\stackrel{\circ}{m}$ \\
\hline & 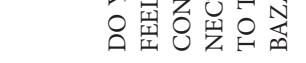 & & & F & & 留 & & & & & & & & $\begin{array}{l}\infty \\
\stackrel{\infty}{m}\end{array}$ & 出 & & $\stackrel{\substack{i \\
i}}{\pi}$ & 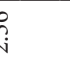 & z \\
\hline & $\infty n^{t} z$ & बें & अें & $\stackrel{\circ}{\Rightarrow}$ & $\stackrel{\circ}{\circ}$ & ふें & बें & $\begin{array}{l} \\
\text { लें } \\
\text { ते }\end{array}$ & 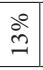 & 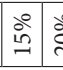 & ذిे & 总 & 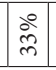 & $\therefore$ & $\begin{array}{l}\circ \\
\circ\end{array}$ & 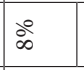 & ¿ें & 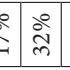 & बें \\
\hline & 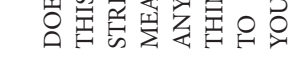 & & & ণิ & & 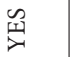 & & & 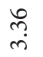 & & 这 & & & $\begin{array}{l}\infty \\
\dot{m} \\
\dot{m}\end{array}$ & 贸 & & 贫 & 案 & $\stackrel{̊}{\gtrless}$ \\
\hline & 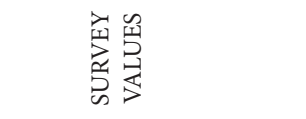 & 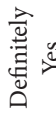 & $\cong$ & ت্ّ & $\stackrel{2}{z}$ & 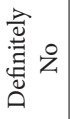 & 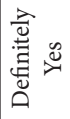 & $\stackrel{\leftrightarrow}{\approx}$ & $\mid$ & 8 & 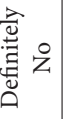 & 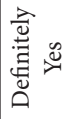 & $\cong$ & 吾 & 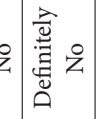 & 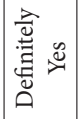 & 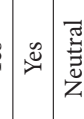 & $\stackrel{\mathrm{z}}{\mathrm{z}}$ & 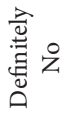 \\
\hline & 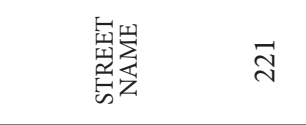 & 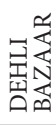 & & & & & 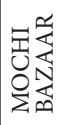 & & & & & 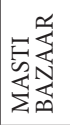 & & & & 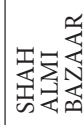 & & & \\
\hline
\end{tabular}


Higher place attachment in the Delhi street was due to its presence of more historic structures as anticipated by hypothesis 2. Individuals of Delhi Street are living and working in the same place for years now and individuals from the entire walled city go to this bazaar for social interactions. Individuals did move out from Delhi Street because of the historic preservation as the public authority paid them to move out. From the Masti and Mochi streets, fewer individuals moved out, as this space isn't yet conserved. These two streets have fewer social connections in contrast with the Delhi street but individuals are attached to them due to the mosque, squares, while in the Mochi bazaar individuals are appended because of their Shia celebration. Individuals living near the Historic structures for many years had higher place connections because of their history, as they know their culture and environment more so hypothesis 3 additionally becomes true. Each street contrasts in the national or inhabitants imagery however mostly they picked Dehli street as individuals are joined in more national terms, this Dehli street impeccably characterizes their way of life, their personality, their values, their customary attributes, and planning values so hypothesis 4 likewise turned out to be valid.

This Shah-Almi street needs to consider these focuses for improving it as these focuses can serve to recover it, for example, making significant activities, occasions and situations. The street should consider some tactile experimentation and should offer access to walk ability. There ought to be visual clarity upon the public area and provide an opportunity to encounter the space Abusaada and Elshater (2020). The space ought to be modified such that the People consider it as themselves like they had a belong there, peoples personalization can assist them with feeling to be of a place as they will give their implications to the space and in conclusion, the historic and individual character will be added. Abusaada and Elshater's (2020) study shows moving environments and the performance quality of public spaces. Their investigations can be utilized as a base for the future expansion of this study for the better improvement of the streets spaces which need rehabilitation as it includes fieldwork examination and provided a method to give back the quality in the spaces which lack now.

\section{Findings and discussions}

Attachment to a place can emerge out of the actual features of the site likewise it can also come from non-actual parts of the site, likewise the social perspective. Kasarda and Janowitz (1974) discussed the place attachment that relies upon individuals' associations with its current built environment and the local community. Additionally, the association stressed by Jacobs (1961) lights the concept of visual connection to the streets from the inside, which permits the space to stay dynamic. This connection creates interest and provides security for its area. Shah-Almi bazaar lacks this character as it doesn't incorporate a Jharoka or a balcony and it does not permit them to be associated with its local area. Clayton (2003) and Manzo (2003) gave their thought regarding the surrounding built fabric that an individual must be dynamic in the public also for attachment to take place. If the space allows relaxation time then that means the place is special. They also suggested that space should always provide an opportunity for an event to take place. Social associations among individuals are a solid marker for a local Attachment as suggested by Raymond et al. (2010). The public develops its acceptance from shared recognition and shared morals communicated by their national practices and their symbols and they join the individuals to basic commitments and obligations, which are fundamental for human growth. Scannel and Gifford (2014) talked about place attachment are because of certain elements, which incorporate a person's very own experience, the public activities, the actual physical characteristics, or even its green features. The walled city helps to satisfy their social needs. The actual characteristics incorporate; the concealed streets, alongside the visual solace of the relative multitude of tones of nature, which is their conventional utilization of the brick. People are likewise connected to the Dehli, Mochi, and Masti however unfortunately Shah-Almi road needs social intervention. Individuals are joined to a place through its local. If there is a local contribution to a city then that city will be great to live in. Lynch discusses that if a city celebrates human activities then it can guarantee a trigger for a memory turn up and can build a passionate bind with its user. As depicted by Elshater (2015) notable landmarks mirror the past and it assists the client with understanding their lifestyles. Eliot says that for a place to be there should be some dependence on prior old practices. Pallasma and McCarte (2012) say that culture influences our exercises, our convictions, and our practices in architecture. Landmarks do assume a critical part in improving the comprehensibility of place as they give them an identity, as well as, provide fascination for the outsiders. Perkins and Long (2002) referred that the feeling of having a place in a local area is established from the touchy associations with its familiar history. Both the Masti and Dehli road has their significance in the Mughal history and that is the reason their connection is more with its cultural identity. There are complicated components that consider these associations with incorporates of senses, program, and function, or built features, other elements that are essential for communities identity are symbols. These symbols hold significance for a bigger local however it might likewise be another interesting component to individuals of that particular local area these extra components of readability assists the individuals with arranging themselves to orient themselves in their unique context. These components provide warmth from them or they give structure to their settings or safety.

The spaces of the Walled City of Lahore have the closeness of volumes and so unites the hard and softmargins. even the spice market is joined together to lead to the cozy culture of the streets in the Walled City of Lahore. A little niche on this street and the width of the streets are all 


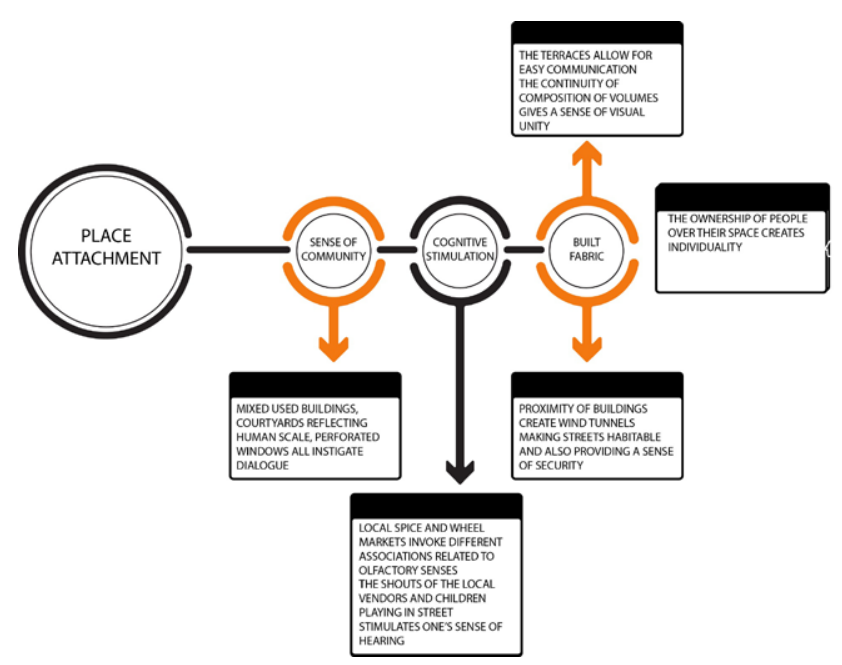

Figure 6. Characteristics of the walled city, which creates place attachment (Zahid, 2021)

fragments of its time that encounter an experience of the Medieval period. Although the width and material used hold symbolic meanings for all the guests. The chart below in Figure 6 puts forwards the individual's attachments of the streets of the inner city which can improve place connection for spaces which lacks now.

While place attachment is not simply a brief of cultural and social experience, there are also little elements that might not have a direct relation to the built environment but they all contribute to the everyday experience for the local inhabitants which by the end creates place attachment. People's attachment depends on prompt symbols, which are present in the surrounding environment. The smell of the spices, the sound made in the market, seeing ladies reporting from their patios are all that add to the social character of the place. Components that build a relationship for the occupants however when considering them as one component these are defined as creating individual meaning. Some things improve the significance of the streets of the walled city, which are the historical symbols that have strived for more than many years to remind the enhanced craftsmanship and culture of Lahore. These symbols vary from constructed features like Jharoka, which mirrors the way of life of the walled city, and the utilization of bricks, even the size of the bricks doesn't relate to the modern brick, the fresco paintings are all reminders of Mughals central love for workmanship. These symbols add to the combined meanings, which by the end improves the person's connection to the place regardless of whether he is from another location.

\section{Conclusions}

A Street is a place for individuals to come together and interact. They build the character for a city by portraying its metropolitan planning tactics, making it a place friendly for its people. These days the significance of streets has been abandoned because of the quick approval of the worldwide thoughts of avenues and boulevards. Individuals moved their interests in the nineteenth century when the new advancement in the new age came about in architecture and metropolitan design. Individuals failed to remember what was significant for the city. The significant care for this investigation was to inspect the shared memory of its individuals, and the streets of the notable city. Individuals attach themselves to places so they can make logic of a place as they provide implications to a space. The significant concern of the study was to see the joint memory of the individuals about the streets of the notable city.

The study presumed that the streets of the Walled City of Lahore preserve their historic settings bodily and socially. The aim was to look at the place connection esteems today. As the majority of individuals moved out and will keep on moving out if the pieces of the streets are improved to live at only than it will provide better working. The paper finds the street needs and thinks about future solutions; the inquiry is "are they actually associated to those old street qualities" The exploration made examinations between various streets of the Walled City of Lahore with the determinants of place attachment, identity and memory through their users encounters. The outcomes uncovered that there was an extraordinary inclination towards the place connection in the notable streets of the walled city but just a single street needs improvement which is the Shah-Almi Bazaar Street. In 1947 during the India and Pakistan independence there was an enormous fire, which made the entire street to caught fire and thus lost everything its place because of the fire and the people as they moved to the new parts. From the analysis the place which has the most attachment is considered to be the most social and traditional. Physical features does create place identity as they give place a character, this makes them feel belonged to the street. People are connected to a street for many reasons as some are connected by their known meanings such as history, culture, or shared values. Place attachment although has a complex phenomenon but can be narrowed down to some elements of design which include place quality; Aesthetics, the ways of life, meanings/character; understanding of the environment, and a feeling of a place. A space like Shah-Almi bazaar is follows function; form; location; open and closed spaces; confines; circulation and private and public parts of the design. Space does not follow the place principles. The street which lacks now is Shah-Almi street as seen from the study it lacks and the most prominent lacking is the place identity. If the people are given a chance to present their personalization then it will get its place a meanings/character from its people. The street should now focus on providing opportunities for interaction where they introduce new activities for the regeneration of the street spaces. Tactile experiences could give the space a unique touch for its user. The street also lacks pedestrian flow and should consider giving access to the walk ability for its people so they can come and join the street for social reasons, etc. Further investigation can be stretched out for the Shah-Almi street as it lacks quality and the study should consider its client needs. A questionnaire could be made to make the inhabitants pick various components which exist in the internal streets of the Shah-Almi 
bazaar as the main bazaar was burnt down in 1947. These characteristics if put forwards than that could be projected onto the bazaar street for its improvement. Now, the Walled City of Lahore is being preserves as a product and this intervention is creating privatization of the current structures. The issue which privatization brings is marginalization and the current user who consumed the current spaces legitimately or wrongfully is wiped out from the current condition. This is done to make the region just reasonable for a specific class. New food road of the walled city and the Shah-Almi road is the ideal model for this and it caused its street to lose its identity since character is made from objects as well as from its local. Marginalization ought to be considered such that the capitalized regions must carry stability with its built fabric and it can be done with local contribution so the street which is working impeccably now is kept up with by its qualities. This can assist the two parties and thus supporting their business in return.

The review was limited to the symbols of its fabricated environment by its present local but this thought was simply considered as a general. When studied inside and out it was seen that few parts don't have connection or hold significance for their local. The point of the paper writing was to raise the attention to the legislative associations, whose activities are to underestimate their local by moving them in various regions outside the walled city. This activity would give an adverse outcome soon if they continue their plans of marginalization. This will affect the noteworthy streets to lose its identity as character isn't just framed with the constructed fabric but it is made with the local as well, As Shah-Almi road individuals keep on moving out it has effectively lost its attachment and identity from its local community.

\section{Acknowledgements}

This research was adapted from Armaghan Zahid's master's thesis entitled "Measuring Place Attachment, Identity, and Memory in Urban Spaces: Case of Walled City Lahore, Pakistan" which was supervised by Assist. Prof. Dr. Damla Misirlisoy and submitted to the European University of Lefke in 2021.

\section{References}

Abusaada, H., \& Elshater, A. (2020). Urban design assessment tools: A model for exploring atmospheres and situations. Proceedings of the Institution of Civil Engineers - Urban Design and Planning, 173(6), 238-255.

https://doi.org/10.1680/jurdp.20.00025

Abusaada, H., \& Elshater, A. (2021). Effect of people on place making and affective atmospheres in city streets. Ain Shams Engineering Journal, 12(3), 3389-3403.

https://doi.org/10.1016/j.asej.2021.04.019

Al Braifkani, E., \& Günçe, K. (2021). Hybrid space as a conceptual framework for adaptation. Journal of Design for Resilience in Architecture \& Planning, 1(1), 1-14.

https://doi.org/10.47818/DRArch.2020.v1i1001
Bellelli, G., Curci, A., \& Leo, G. (2010). Social and cognitive determinants of collective memory for public events. Cambridge University Press.

https://doi.org/10.1017/CBO9780511611162.034

Bukowiecki, L., Wawrzyniak, J., \& Wróblewska, M. (2020). Duality of decolonizing: Artists' memory activism in Warsaw. Heritage \& Society, 13(1-2), 32-52.

https://doi.org/10.1080/2159032X.2021.1898076

Canizaro, V. (2007). Architectural regionalism: Collected writings on place, identity, modernity, and tradition. Princeton Architectural Press.

Clayton, S. (2003). Environmental identity: A conceptual and operational definition. S. D. Clayton \& S. Opotow, (Eds.), Identity and the environment: The psychological significance of nature. MIT Press.

https://doi.org/10.7551/mitpress/3644.001.0001

Kyle, G., \& Chick, G. (2007). The social construction of a sense of place. Leisure Sciences, 29(3), 209-226.

https://doi.org/10.1080/01490400701257922

Eliot, T. S. (1949). Notes towards the defination of culture. Harcourt, Brace and Company.

Elshater, A. M. (2015). Urban design redux: Redefining a professional practice of specialization. Ain Shams Engineering Journal, 6(1), 25-39. https://doi.org/10.1016/j.asej.2014.08.004

Elshater, A. (2012). New urbanism principles versus urban design dimensions towards behavior performance efficiency in Egyptian neighbourhood unit. Procedia - Social and Behavioral Sciences, 68, 826-843.

https://doi.org/10.1016/j.sbspro.2012.12.270

Ettehad, S., Karimi Azeri, A., \& Kari, G. (2014). The role of culture in promoting architectural identity. European Online Journal of Natural and Social Sciences 2014, 3(4), 410-418.

Ezdi, R. (2009). The dynamics of land use in lahore inner city: The case of mochi gate. Environment and Urbanization, 21(2), 477-500. https://doi.org/10.1177/0956247809342776

Fazl, A. A. (1978). The Ain i Akbarí. Asiatic Society of Bengal.

Geroter, Y. (2007). Aesthetics in architecture (3rd ed.). Martyr Beheshti University Press.

Halbwachs, M. (1925). Collective memory. The University of Chicago Press.

Haughton, J., \& Khandker, S. (2009). Handbook on poverty and inequality. World Bank Publications.

Hay, R. (1998). Sense of place in developmental context. Journal of Environmental Psychology, 18(1), 5-29. https://doi.org/10.1006/jevp.1997.0060

Hidalgo, M. C., \& Hernandez, B. (2001). Place attachment: Conceptual and empirical questions. Journal of Environmental Psychology, 21(3), 273-281. https://doi.org/10.1006/jevp.2001.0221

Jacobs, J. (1961). The death and life of great American cities. Vintage Books.

Jackson, J. B. (1995). A sense of place, a sense of time. Design Quarterly, 164, 24-27. https://doi.org/10.2307/4091350

Kasarda, J., \& Janowitz, M. (1974). Community attachment in mass society. American Sociological Review, 39(3), 328-339. https://doi.org/10.2307/2094293

Kals, E., Schumacher, D., \& Montada, L. (1999). Emotional affinity toward nature as a motivational basis to protect nature. Environment and Behavior, 31(2), 178-202. https://doi.org/10.1177/00139169921972056

Kaltenborn, B. P. (1997). Nature of place attachment: A study among recreation homeowners in Southern Norway. Leisure Sciences, 19(3), 175-189. 
Kølvraa, C., \& Knudsen, B. T. (2020). Decolonizing European colonial heritage in urban spaces - An introduction to the special issue. Heritage \& Society, 13(1-2), 1-9.

Lalli, M. (1992). Urban-related identity: Theory, measurement, and empirical findings. Journal of Environmental Psychology, 12(4), 285-303. https://doi.org/10.1016/S0272-4944(05)80078-7

Lewicka, M. (2011). Place attachment: How far have we come in the last 40 years? Journal of Environmental Psychology, 31(3), 207-230. https://doi.org/10.1016/j.jenvp.2010.10.001

Low, S. M. (1992). Place attachment: A conceptual inquiry. In I. Altman \& S. M. Low (Eds.), Human Behavior and Environment (Advances in Theory and Research): Vol. 12. Place attachment (pp. 1-12). Springer.

https://doi.org/10.1007/978-1-4684-8753-4_1

Lynch, K. (1960). The image of the city. MIT Press.

Manzo, L. (2003). Relationships to non-residential places: Towards a reconceptualization of attachment to place. Journal of Environmental Psychology, 23(1), 47-61.

Marcus, C. C. (1992). Environmental memories. In I. Altman \& S. M. Low (Eds.), Place attachment. Springer. https://doi.org/10.1007/978-1-4684-8753-4_5

Matthew Carmona, T. H. (2003). Public spaces, urban spaces: The dimensions of urban design. Routledge.

McAndrew, F. T. (1998). The measurement of "rootedness" and the prediction of attachment to home-towns in college students. Journal of Environmental Psychology, 18(4), 409-417. https://doi.org/10.1006/jevp.1998.0078

Merchant, S. (2017). Analyzing the city urban form of Lahore. C.E.P.T University.

Misztal, B. (2003). Theories of social remembering. Open University Press.

Moore, R. L., \& Graefe, A. R. (1994). Attachments to recreational settings: The case of rail-trail users. Leisure Sciences, 16(1), 17-31. https://doi.org/10.1080/01490409409513214

Mumtaz, K. K. (1985). Architecture in Pakistan: A Mimar book. Concept Media Pte Ltd.

Pallasma, J., \& McCarter, R. (2012). Understanding architecture. Phaidon.

Pakistan Environmental Planning and Architectural Consultants Limited. (1993). The Walled city of Lahore. Lahore Development Authority.

Perkins, D. D., \& Long, D. A. (2002). Neighborhood sense of community and social capital: A multi-level analysis. In Psychological sense of community: Research (pp. 291-318). Springer. https://doi.org/10.1007/978-1-4615-0719-2_15
Proshansky, H., Fabian, A., \& Kaminoff, R. (1983). Place-identity: Physical world socialization of the self. Journal of Environmental Psychology, 3(1), 57-83.

https://doi.org/10.1016/S0272-4944(83)80021-8

Raymond, C. M. (2010). Results of the 2010 Northern and York rural landholder survey. Centre for Rural Health and Community Development, University of South Australia.

Raymond, C., Brown, G., \& Weber, D. (2010). The measurement of place attachment: Personal, community, and environmental connections. Journal of Environmental Psychology, 30(4), 422-434. https://doi.org/10.1016/j.jenvp.2010.08.002

Relph, E. (1976). Place and placelessness. Pion.

Sampson, K. A., \& Goodrich, C. G. (2009). Making place: Identity construction and community formation through "sense of place" in Westland, New Zealand. Society \& Natural Resources, 22(10), 901-915.

Scannell, L., \& Gifford, R. (2014). The psychology of place attachment. In Environmental psychology: Principles and practice. Optimal Books.

Taha, D., \& Gami, G. (2010). Decoding the DNA of places, towards exploring a deeper layer of urban sustainability. In The 2nd International Conference on Sustainable Architecture and Urban Development (pp. 307-324). Queensland University of Technology.

Tuan, Y. (1977). The prespectives of experience. University of Minnesota Press.

Un-Habitat. (2011). Cities and climate change: Global report on human settlements. Earthscan. https://doi.org/10.4324/9781849776936

Walled City of Lahore Authorities. (2021). Website includes all the maps of the walled city of Lahore. http://walledcitylahore. gop.pk/maps/

Williams, D. R., \& Vaske, J. J. (2003). The measurement of place attachment: Validity and generalizability of a psychometric approach. Forest Science, 49(6), 830-840.

Williams, D. R., \& Stewart, S. I. (1998). Sense of place: An elusive concept that is finding a home in ecosystem management. Journal of Forestry, 96(5), 18-23.

Williams, D. R., Patterson, M. E., Roggenbuck, J. W., \& Watson, A. E. (1992). Beyond the commodity metaphor: Examing emotional and symbolic attachment to place. Leisure Sciences, 29-46. https://doi.org/10.1080/01490409209513155

Yasin, A. (2012). The lost romance of the streets of Lahore. In Portrait of Lahore: Lahore $\mathrm{Nu}$ Salaam. https://docplayer. net/100023539-Portrait-of-lahore-lahore-nu-salam.html

Zahid, A. (2021). Measuring place attachment, identity, and memory in urban spaces: Case of Walled City Lahore [Unpublished master thesis]. European University of Lefke. 